\title{
Grazing by mesozooplankton from Kiel Bight, Baltic Sea, on different sized algae and natural seston size fractions
}

\author{
F. Sommer ${ }^{1, *}$, H. Stibor ${ }^{2}$, U. Sommer ${ }^{3}$, B. Velimirov ${ }^{1}$ \\ 'Institut für Medizinische Biologie, Universität Wien, Abteilung Allgemeine Mikrobiologie, Währinger Straße 10, \\ 1090 Wien, Austria \\ ${ }^{2}$ Zoologisches Institut, Ludwig-Maximilians-Universität, Abteilung Aquatische Ökologie, Karlstrafe 23-25, \\ 80333 München, Germany \\ ${ }^{3}$ Institut für Meereskunde, Christian-Albrechts-Universität, Abteilung Meeresbotanik, Düsternbrooker Weg 20, \\ 24105 Kiel, Germany
}

\begin{abstract}
Grazing experiments were conducted with natural mesozooplankton from Kiel Bight, Germany, using radioactive labelled phytoplankton cultures and seston size fractions. The results of experiments using phytoplankton cultures indicated that bivalve veligers performed highest clearance of particles within a size range of 4.7 to $6.3 \mu \mathrm{m}$, whereas optimum particle size for copepods was $15 \mu \mathrm{m}$. The results of experiments using labelled natural seston size fractions identified bivalve veligers and appendicularians as those responsible for the removal of particles within the smallest size class $(<2 \mu \mathrm{m})$. Seston size fractions larger than $5 \mu \mathrm{m}$ were mainly cleared by copepods and nauplii. As particle size increased, the contribution of copepod clearance to total zooplankton clearance within size classes increased from $57 \%(<5 \mu \mathrm{m}$ size class) to more than $81 \%$ (30 to $100 \mu \mathrm{m}$ size class). When the nauplii clearance rates were included, the total copepod clearance accounted for 90 to $97.6 \%$ of the total volume cleared of particles bigger than $10 \mu \mathrm{m}$. Despite low abundances of bivalve veligers and appendicularians in Kiel Bight at the time of the experiment, we calculated that approximately 10 and $8.5 \%$, respectively, of the carbon ingested by total mesozooplankton was due to veliger and appendicularian grazing. The importance of bivalve veligers might be seen in their grazing on seston particles that escape predation by copepods and on the amount of energy that is therefore directed from the water column to the benthos when larvae settle.
\end{abstract}

KEY WORDS: Bivalve veligers $\cdot$ Copepods $\cdot$ Size-selectivity $\cdot$ Community grazing

\section{INTRODUCTION}

In most marine pelagic ecosystems calanoid copepods are the most abundant mesozooplankton guild and provide the bulk of food for commercially important planktivorous fish (Cushing 1975). Therefore, in terms of energy, the main carbon flow from phytoplankton towards fish stocks is expected to be mediated via copepods. Gelatinous zooplankton and meroplanktonic larvae can be regarded as planktonic groups that temporarily direct energy out of this food

\footnotetext{
•E-mail: a9101292@unet.univie.ac.at
}

chain to the benthos (settling meroplanktonic larvae) or into trophic guilds (e.g. coelenterates), which are not heavily grazed upon by commercial fish stocks (Cushing 1975).

Copepods have been found to feed on a wide range of particles of auto- and heterotrophic seston organisms (for review Kleppel 1993) which can be selectively captured (Alcarez et al. 1980), tested for their nutritional quality (DeMott 1988, 1989) and perceived by specialized mechanoreceptors located on the first antennae (Bundy et al. 1998). Although the freshwater copepod Diaptomus sicilis has been found to ingest particles as small as $\leq 4 \mu \mathrm{m}$ due to a passive feeding mode (Vanderploeg \& Pfaffenhöfer 1985), optimum particle sizes for 
copepods reported in the literature usually lie beyond $10 \mu \mathrm{m}$ (Harris 1982, Vanderploeg \& Pfaffenhöfer 1985, Berggreen et al, 1988, Nakamura \& Turner 1997). In contrast, meroplanktonic larvae, such as bivalve veligers, have been reported to ingest particles as small as heterotrophic bacteria (Prieur 1983, Douillet 1993) or the cyanobacterium Synechococcus (Gallager et al. 1994). Whereas some authors have found selective grazing by bivalve veligers on particles $>10 \mu \mathrm{m}$ (Fritz et al. 1984) or even $>20 \mu \mathrm{m}$ (Baldwin \& Newell 1991), a preference of particles sized $\leq 4 \mu \mathrm{m}$ has been reported by others (Riisgård et al 1980, Baldwin 1995).

We performed grazing experiments with the natural mesozooplankton composition present at Kiel Bight, Germany $\left(54^{\circ} 19^{\prime} 27^{\prime \prime} N, 10^{\circ} 08^{\prime} 01^{\prime \prime} \mathrm{E}\right)$. Major marine groups such as echinoderm larvae and salps are missing in the plankton of the Baltic Sea, reflecting the general characteristic of the Baltic as an area of uniquely low species biodiversity. Large mussel banks down to $30 \mathrm{~m}$ depth are formed by Mytilus edulis dominating animal biomass (Kautsky 1981), which may be one explanation why bivalve veliger larvae compose up to $28 \%$ of the mesozooplankton community in Kiel Bight (Fig. 1).

Using radioactive labelled cultures of marine phytoplankton and seston size fractions as tracers, we (1) evaluated clearance rates for copepods and bivalve veligers in order to determine optimum particle sizes, (2) calculated the contribution of the main mesozooplankton guilds to total zooplankton grazing within seston size fractions and (3) quantified the amount of carbon ingested by zooplankton guilds.

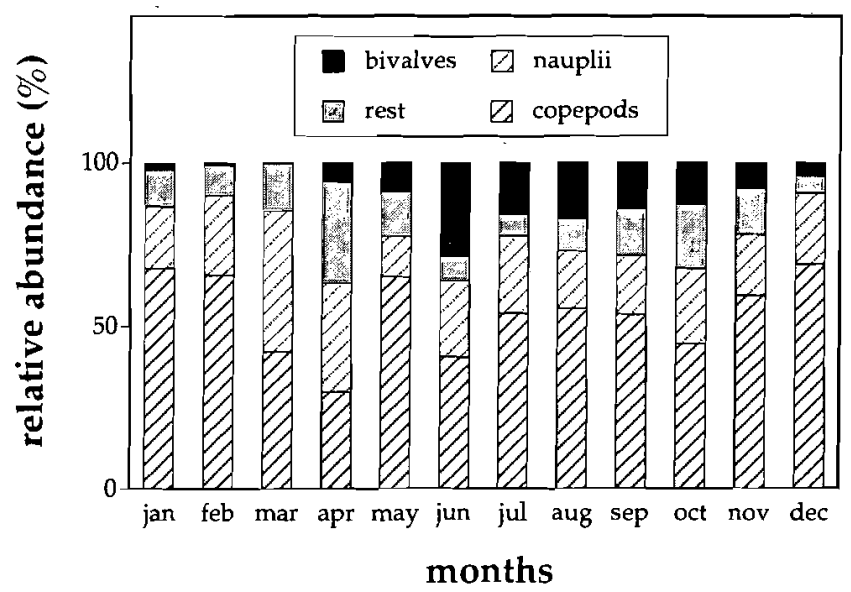

Fig. 1. Relative monthly mean abundances of zooplankton (1985 to 1992) at Boknis Eck, Kiel Bight. Data used to calculate stacks were taken from Behrends (1996)

\section{MATERIAL AND METHODS}

Cultures. Various cultures of marine phytoplankton were obtained from the Department of Marine Botany, Institut für Meereskunde (Table 1). The algae were classified to the species level except for 2 that are referred to as pennate diatoms 1 and 2 . All phytoplankton cultures were grown in $0.2 \mu \mathrm{m}$ membranefiltered Baltic seawater medium to which nutrients and trace metals were added (Von Stosch \& Drebes 1964; modified). Surface seawater was filtered through $0.8 \mu \mathrm{m}$ membrane filters in order to remove

Table 1. Phytoplankton cultures serving as träcers in grazing experiments: values represent means of cell dimensions $(n=50)$ and of clearance rates $(n=3)$. Values in brackets are $1 \mathrm{SD}^{*}{ }^{*} \mathrm{p}<0.05_{i}{ }^{*} \mathrm{p}<0.005$

\begin{tabular}{|c|c|c|c|}
\hline \multirow[t]{2}{*}{ Tracer } & \multicolumn{2}{|c|}{ Cell dimensions } & \multirow{2}{*}{$\begin{array}{l}\text { Clearance rate } \\
\left(\mu l \text { ind. }{ }^{-1} h^{-1}\right)\end{array}$} \\
\hline & Length or diameter $(\mu \mathrm{m})$ & Width $(\mu \mathrm{m})$ & \\
\hline \multicolumn{4}{|l|}{ Bivalve veligers } \\
\hline Heterotrophic bacteria & $<0.8$ & $<0.8$ & $5.2(1.44)$ \\
\hline Chlorella sp. & $2.7(0.4)$ & - & $3.4(1.35)$ \\
\hline Emiliana huxleyi & $4.7(0.6)$ & - & $17.3(4.08)^{* *}$ \\
\hline Pennate diatom 1 & $6.3(0.3)$ & $4.0(0.5)$ & $21.9(6.18)^{* *}$ \\
\hline Prymnesium parvum & $8.7(0.9)$ & - & $5.3(2.91)$ \\
\hline Chrysochromulina polylepis & $9.7(0.4)$ & $9.0(0.7)$ & $2.7(0.90)^{\mathrm{a}}$ \\
\hline Thallassiosira weissflogii & $10.0(0.4)$ & $5.2(0.7)$ & $2.1(0.94)$ \\
\hline Pennate diatom 2 & $14.3(2.5)$ & $7.0(1.3)$ & $0.97(0.45)^{\mathrm{a}}$ \\
\hline Heterocapsa triquetra & $21.0(1.8)$ & $15.3(1.2)$ & $1.5(0.88)$ \\
\hline \multicolumn{4}{|l|}{ Copepods } \\
\hline Pennate diatom 1 & $5.6(0.7)$ & $5.0(0.4)$ & $21.9(3.16)$ \\
\hline Emiliana huxleyi & $6.3(1.1)$ & - & $13.2(0.59)$ \\
\hline Chrysochromulina polylepis & $9.8(1.9)$ & $8.3(0.7)$ & $21.2(5.46)$ \\
\hline Thalassiosira weissflogii & $15.0(2.0)$ & $8.8(0.9)$ & $58.1(17.22)^{*}$ \\
\hline Nitzschia closterium & $49.5(3.3)$ & $3.5(0.3)$ & $26.7(7.14)$ \\
\hline Nitzschia longissima & $73.0(4.1)$ & $7.2(0.6)$ & $25.1(12.85)$ \\
\hline${ }^{\mathrm{a}} \mathrm{n}=2$ & & & \\
\hline
\end{tabular}


all cells except suspended heterotrophic bacteria. The $0.8 \mu \mathrm{m}$ filtrate as well as algal cultures were stored at $18 \pm 0.5^{\circ} \mathrm{C}$ and 80 to $100 \mu \mathrm{E} \mathrm{m}^{-2}$ $\mathrm{s}^{-1}$ (PAR 400 to $800 \mathrm{~nm}$; LiCor Li 189). Algae were selected for grazing experiments in accordance with the reported range of particle sizes ingested by copepods and bivalve veligers, respectively. On the day prior to grazing experiments, algal cell dimensions of at least 50 individuals were determined to the closest $0.5 \mu \mathrm{m}$ at $630 \times$ magnification under a Zeiss Axioplan microscope (Table 1).

Seston size fractions. Baltic surface seawater was serially fractionated in order to establish the (1) 30 to $100 \mu \mathrm{m}$, (2) 10 to $30 \mu \mathrm{m}$, (3) 5 to $10 \mu \mathrm{m}$ and $(4)<5 \mu \mathrm{m}$ seston size classes. Part of the $5 \mu \mathrm{m}$ fraction was filtered through a $2.0 \mu \mathrm{m}$ membrane filter creating the $(5)<2 \mu \mathrm{m}$ size class. Medium (as above) was added to $80-100 \mathrm{ml}$ of each fraction and stored in $600 \mathrm{ml}$ TC (tissue culture) flasks at $11 \pm 0.5^{\circ} \mathrm{C}$ and at 80 to $100 \mu \mathrm{E} \mathrm{m}^{-2} \mathrm{~s}^{-1}(12 \mathrm{~h}$ light:12 h dark cycle). Steps of fractionation and radioactive labelling are given in Fig. 2.

The taxonomic composition of the seston size fractions, as determined in $10 \mathrm{ml}$ Utermöhl chambers (Drebes 1974), remained fairly constant over the growth period. Because of cell growth and the formation of colonies, the abovedescribed sieving and filtration procedure was repeated on the day of radioactive labelling in order to attain the original size cut-off of seston size classes. After repeating the fractionation procedure, species composition of all size fractions was determined in $10 \mathrm{ml}$ Utermöhl chambers and additionally, by means of epifluorescence microscopy (Leica Type DMRB) for both the $<2$ and $<5 \mu \mathrm{m}$ size fractions (Table 2). Samples for epifluorescence microscopy were prepared by filtering $5 \mathrm{ml}$ of each seston size fraction onto black membrane filters $(0.2 \mu \mathrm{m}$ pore size) and staining them with $400 \mu \mathrm{l}$ of DAPI (4', 6-diamino-2-phenylindole) solution $\left(10 \mu \mathrm{g} \mathrm{ml}^{-1}\right)$ for $10 \mathrm{~min}$.

Radioactive labelling. Twenty-four hours prior to the grazing experiments, $40 \mathrm{ml}$ of each seston size fraction or phytoplankton culture was labelled with $1 \mathrm{ml}$ of ${ }^{14} \mathrm{C}$ bicarbonate $\left(\mathrm{NaH}^{14} \mathrm{CO}_{3 i}\right.$ Hartmann Analytic, Braunschweig; specific activity $=25 \mu \mathrm{Ci} \mathrm{ml}{ }^{-1}$; final concentration $=0.6 \mu \mathrm{Ci} \mathrm{ml}^{-1}$ ). Heterotrophic bacteria were inoculated with $5 \mathrm{ml}$ of radioactive glucose (Hartmann Analytic, Braunschweig; specific activity $=5 \mu \mathrm{Ci} \mathrm{ml}{ }^{-1}$ i final concentration $=0.6 \mu \mathrm{Ci} \mathrm{ml}^{-1}$ ). Due to the presence of cyanobacteria in the $<2 \mu \mathrm{m}$ fraction (Table 2), this
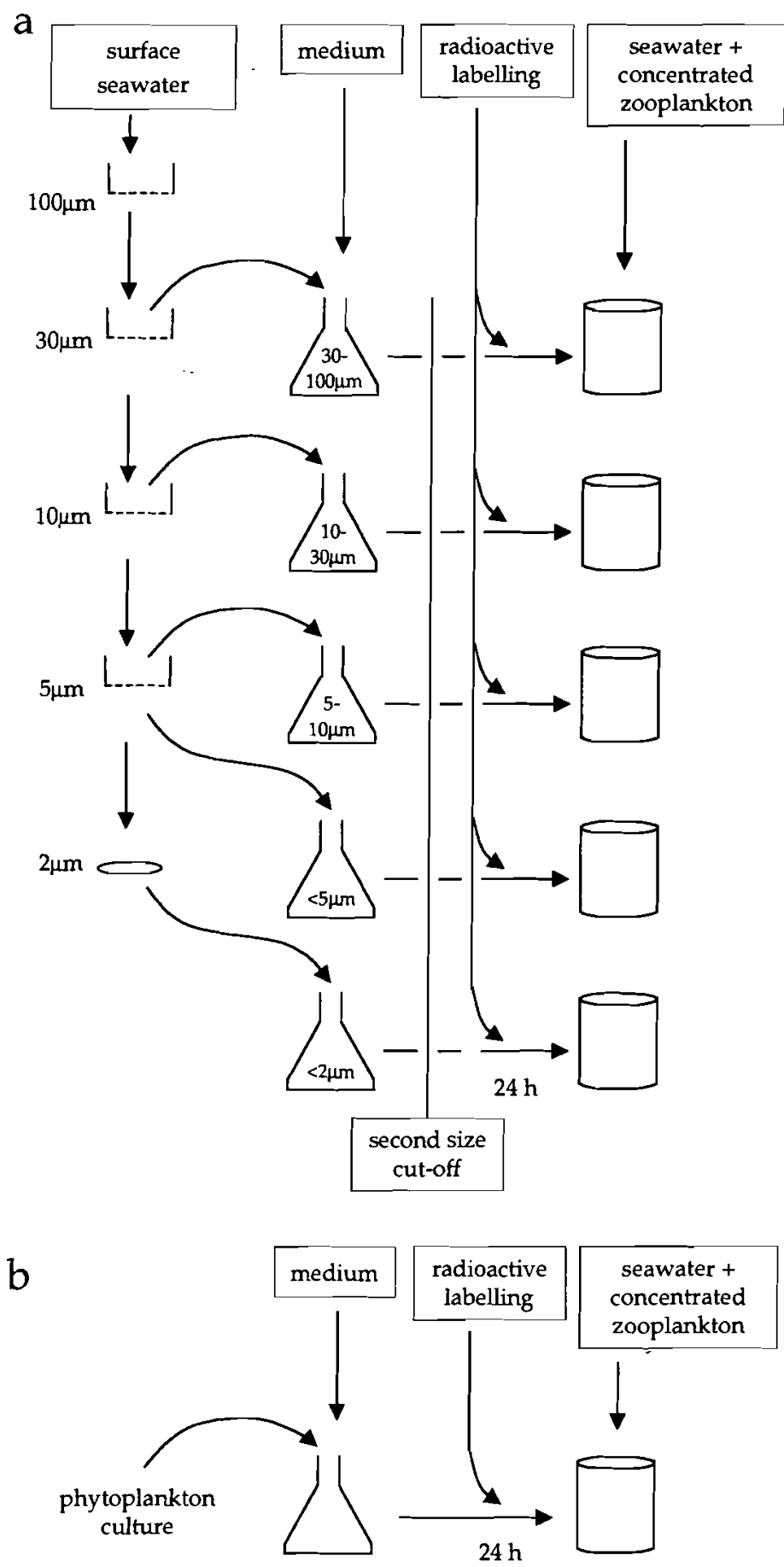

Fig. 2. Scheme illustrating the procedures of plankton fractionation and radioactive labelling in experiments using (a) seston size fractions and (b) phytoplankton cultures. For details see text

size class was labelled with both ${ }^{14} \mathrm{C}$ bicarbonate and radioactive glucose at a final concentration of $1.1 \mu \mathrm{Ci}$ $\mathrm{ml}^{-1}$. The bottles were stored under the same conditions as during growth of the seston size fractions until experiments commenced. 
Table 2. Taxonomic composition of the seston size fractions determined in Utermöhl chambers prior to radioactive labelling

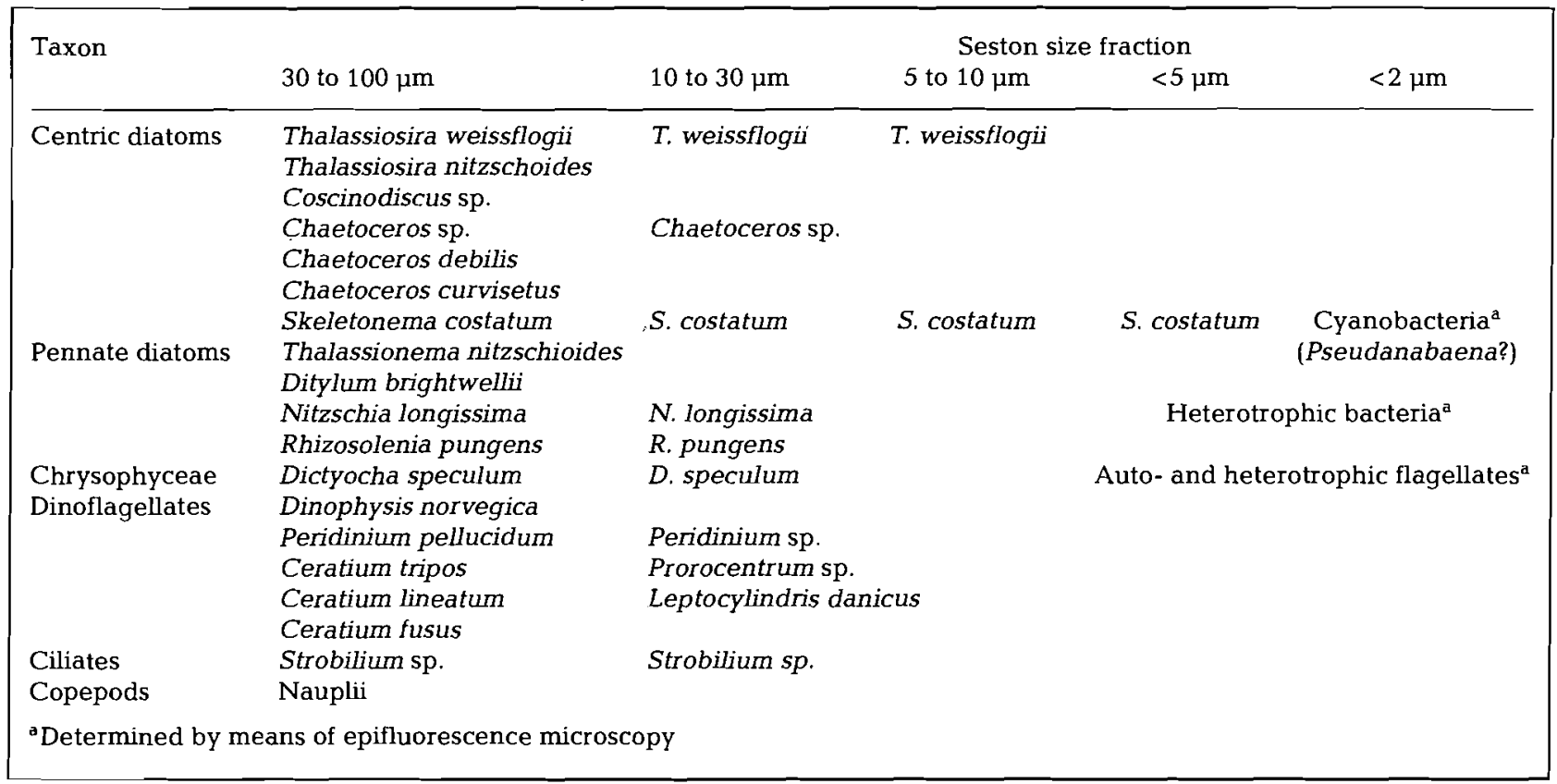

Manipulation of zooplankton. Zooplankton were collected at the institute's pier in Kiel Bight by means of several vertical plankton hauls (mesh size $200 \mu \mathrm{m}$ ). The contents of all plankton hauls were collected in a coolbox that had been previously filled with unfiltered surface water, hence concentrating mesozooplankton $>200 \mu \mathrm{m}$. Concentration was necessary in order to increase the amount of individuals of otherwise numerically poorly represented guilds in the plankton. In the laboratory, glass jars $(800 \mathrm{ml})$ were filled with this seawater and stored under the same conditions as during growth of the seston size fractions. Zooplankton was thereby allowed to adapt to experimental conditions for $2 \mathrm{~h}$ before the beginning of the grazing experiments.

In order to calculate ingestion rates, triplicate samples of surface seawater $(500 \mathrm{ml})$ were first screened through a $100 \mu \mathrm{m}$ sieve (thereby removing zooplankton) and then filtered onto precombusted Whatman $\mathrm{GF} / \mathrm{C}$ filters. Filters were dried for several days at $45^{\circ} \mathrm{C}$ and later analyzed for their carbon content with a Fisons NA $1500 \mathrm{~N}$ elemental analyzer.

Experimental procedures. Triplicate grazing trials were run with each phytoplankton culture or seston size class, respectively, serving as tracers for sizespecific clearance. Radioactive labelled tracer $(10 \mathrm{ml})$ was added to the glass jars containing concentrated zooplankton $(800 \mathrm{ml})$. After a grazing period of $30 \mathrm{~min}$, zooplankton were rapidly anaesthetized with carbonized water. Then zooplankton were collected on a $100 \mu \mathrm{m}$ screen and thoroughly rinsed with $0.2 \mu \mathrm{m}$ filtered seawater in order to remove adhering labelled cells, Finally, zooplankton were transferred into bottles with $0.2 \mu \mathrm{m}$ filtered seawater and preserved with formalin ( $4 \%$ final concentration). Within $2 \mathrm{~d}$, zooplankton were separated into major guilds and counted under a Leica WILD M3Z dissecting microscope before pipetting them into scintillation vials $(20 \mathrm{ml})$. Tissue solubilizer $(0.5 \mathrm{ml}$ of Soluene-350) was added and digestion accelerated by exposing the vials to $40^{\circ} \mathrm{C}$ for several hours. After allowing the scintillation vials to cool off, $10 \mathrm{ml}$ of scintillation cocktail (Ultima Gold, Packard) was added.

Passive adsorption of radioactive tracer by zooplankton was assessed using formalin-killed zooplankton. As for treatments using live zooplankton, $10 \mathrm{ml}$ of each tracer was added to the glass jars containing formalinkilled zooplankton. After $30 \mathrm{~min}$, the zooplankton were removed and further manipulated as mentioned above. Radioactive values assessed for passive adsorption of radioactive tracer were used to correct for values obtained in grazing trials.

In order to determine the amount of radioactivity added to the glass jars in which grazing occurred, $1 \mathrm{ml}$ samples of each labelled tracer were filtered onto Whatman GF/C filters $(0.2 \mu \mathrm{m}$ membrane filters were used for $<0.8 \mu \mathrm{m}$ heterotrophic bacteria and the $<2 \mu \mathrm{m}$ size fraction). Filters were exposed to vapours of concentrated $\mathrm{HCl}$ in order to remove non-incorporated, residual radioactive bicarbonate as ${ }^{14} \mathrm{CO}_{2}$. After $2 \mathrm{~h}$, the filters were placed into scintillation vials $(6 \mathrm{ml})$ together with $5 \mathrm{ml}$ of scintillation cocktail (Lumagel SB, Baker). 
Assessment of clearance and ingestion rates. Radioactivity was measured by means of a liquid scintillation analyzer (TRI-CARB 2100 TR) with external standards for determining efficiencies. Values of radioactivity expressed in dpm were corrected by subtracting background ${ }^{14} \mathrm{C}$ activity and mean passive adsorption of radioactive tracer by formalin-killed zooplankton. Individual clearance rates were computed using the equation provided by Haney (1971):

$F=\left(\mathrm{dpm}\right.$ ind. $.^{-1} / \mathrm{dpm} \mathrm{m}^{-1}$ grazing suspension $) \times(60 / t)(1)$

where $F=$ clearance rate $\left(\mathrm{ml}\right.$ ind. $\left.{ }^{-1} \mathbf{h}^{-1}\right)$, grazing suspension = volume in which grazing occurred and to which radioactive labelled tracer was added $(\mathrm{ml})$, and $t=$ grazing time ( $\mathrm{min})$.

In experiments using seston size fractions, we further calculated group clearance rates of major taxonomic guilds by multiplying individual clearance rates with the appropriate mean abundances calculated for $1 \mathrm{~m}^{3}$ seawater. Group clearance rates of major functional guilds were graphically presented as the percentage of total group clearance of mesozooplankton within each seston size fraction. Ingestion rates of mesozooplankton guilds were calculated by multiplying the sum of group clearance rates of all size fractions with the carbon content assessed on the day of the experiment. When calculating the sum of group clearance rates, clearance for the 2 to $5 \mu \mathrm{m}$ size class was computed by subtracting values obtained in the $<2$ and $<5 \mu \mathrm{m}$ size fractions.

Data analysis. Differences among treatments were tested for significance using 1-way ANOVA. Original data were log-transformed in cases where basic assumptions of ANOVA (Cochran's test, KolmogorovSmirnov) were not fulfilled. Where significant differences were indicated, Tukey's HSD or Tukey's HSD for unequal sample sizes were used at a significance level $p=0.05$. For all statistical analyses STATISTICA 4.0, 1993, software was used.

\section{RESULTS}

\section{Bacteria and phytoplankton cultures}

Mesozooplankton composition and abundance were determined for the experiment in which copepod grazing was tested (Table 3a). Zooplankton was highly concentrated (27-fold) within the experimental jars, with copepods representing more than $90 \%$ of total zooplankton abundance. Among copepods, 3 species were dominant: the cyclopoid Oithona similis and the calanoids Paracalanus parvus and Pseudocalanus elongatus.

Table 3. Mesozooplankton composition in experiments (a) using phytoplankton cultures testing copepods and (b) using seston size fractions. Absolute and relative (\%) mean number of individuals in experimental jars (values in brackets are 1 SD) and in $1 \mathrm{~m}^{3}$ seawater as well as copepod species contribution to total copepod abundance

\begin{tabular}{|c|c|c|c|c|c|c|c|}
\hline \multirow[t]{2}{*}{ Taxonomic group } & \multicolumn{3}{|c|}{- (a) Cultures (copepods) } & \multirow[b]{2}{*}{$\begin{array}{l}\text { Mean } \\
\text { in jars }\end{array}$} & \multicolumn{2}{|c|}{-(b) Seston size fractions } & \multirow[b]{2}{*}{$\begin{array}{l}\% \text { of total } \\
\text { copepods }\end{array}$} \\
\hline & $\begin{array}{l}\text { Mean } \\
\text { in jars }\end{array}$ & $\%$ & $\begin{array}{l}\% \text { of total } \\
\text { copepods }\end{array}$ & & $\begin{array}{c}\text { Mean in } \\
1 \mathrm{~m}^{3} \text { seawater }\end{array}$ & $\%$ & \\
\hline \multicolumn{8}{|l|}{ Holoplankton } \\
\hline Copepods (total) & $150(21.3)$ & 90.1 & & $91(10.2)$ & 5197 & 61.5 & \\
\hline $\begin{array}{l}\text { Paracalanus parvus/ } \\
\text { Pseudocalanus elongatus }\end{array}$ & & & 49 & & & & 30 \\
\hline Centropages hamatus & & & 3 & & & & 11 \\
\hline Temora longicornis & & & 2 & & & & 1 \\
\hline Oithona similis & & & 41 & & & & 55 \\
\hline Acartia sp. & & & - & & & & 3 \\
\hline Harpacticoidea & & & - & & & & 1 \\
\hline Unidentified copepods & & & 3 & & & & - \\
\hline Copepod nauplii & & & 2 & & & & - \\
\hline Nauplii & - & - & & $17(4.5)$ & 977 & 11.6 & \\
\hline Appendicularians & - & - & & $8(2.7)$ & 458 & 5.4 & \\
\hline Chaetognaths & - & - & & $1(0.6)$ & 85 & 1.0 & \\
\hline Ostracods & - & - & & $2(1.0)$ & 123 & 1.5 & \\
\hline Ctenophores & $0.3(0.1)$ & 0.2 & & - & - & - & \\
\hline \multicolumn{8}{|l|}{ Meroplankton } \\
\hline Nectochaeta & $11.7(4.9)$ & 7.0 & & $3(1.3)$ & 181 & 2.1 & \\
\hline Gastropod veligers & $2.2(1.3)$ & 1.3 & & $2(1.2)$ & 152 & 1.8 & \\
\hline Bivalve veligers & $1.9(0.3)$ & 1.1 & & $22(6.5)$ & 1265 & 15.0 & \\
\hline Cyphonautes & $0.3(0.2)$ & 0.2 & & - & - & - & \\
\hline
\end{tabular}


The size spectrum of food types presented to bivalve veligers and copepods is given in Table 1 . The highest clearance rates of bivalve veligers were found for particles sized 6.3 and $4.7 \mu \mathrm{m}$, being insignificantly different from each other. Clearance values of all other particle sizes were significantly lower $(p<0.005)$ from veliger maximum clearance rates, but again differences between these treatments were insignificant. Copepods performed maximum clearance of particles sized $15 \mu \mathrm{m}$. All other particle sizes were cleared at significantly lower rates $(p<0.05)$. The ranges of optimum particle sizes best cleared by bivalve veligers and copepods in our experiments were clearly separated (Fig. 3).

Seston size fractions. Mesozooplankton $>200 \mu \mathrm{m}$ were dominated by nauplii and copepods, which together accounted for more than $73 \%$ of zooplankton composition (Table $3 \mathrm{~b}$ ). Bivalve veligers and holoplanktonic appendicularians represented 15 and $5 \%$ of the mesozooplankton, respectively. All other guilds including gastropod veligers, nectochaetae, chaetognaths and ostracods accounted for less than $7 \%$, being numerically too low to allow reliable assessment of clearance rates. Hence, clearance rates of seston size fractions were only determined for copepods, nauplii, bivalve veligers and appendicularians, which were the 4 most abundant taxonomic guilds.

Mean clearance rates of all 4 guilds ranged from 0 to $138 \mu$ ind..$^{-1} \mathrm{~h}^{-1}$ (Fig. 4). Copepods and nauplii cleared no particles of the $<2 \mu \mathrm{m}$ seston size class. Whereas copepod clearance rates of all size classes were not significantly different, nauplii clearance of particles of the $<5 \mu \mathrm{m}$ size class was significantly higher $(\mathrm{p}<0.05)$ than of the 10 to 30 and 30 to $100 \mu \mathrm{m}$ size classes. In contrast to copepods and nauplii, both bivalve veligers and appendicularians cleared particles of the $<2 \mu \mathrm{m}$

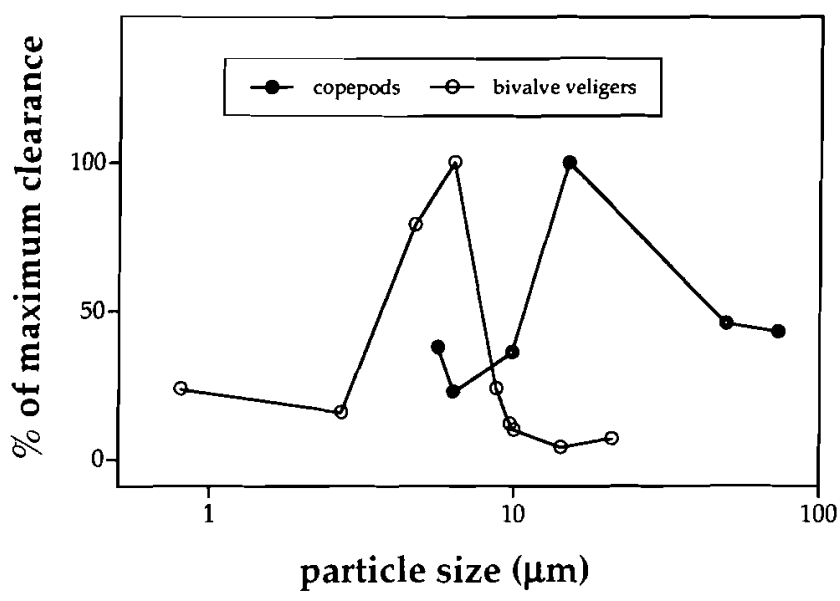

Fig. 3. Clearance curves of mesozooplankton guilds as evaluated in experiments using phytoplankton cultures. Note logarithmic scale of particle size axis size class. Whereas no significant differences could be found between clearance rates for bivalve veligers, all appendicularian clearance rates were significantly different $(p<0.05)$, except for the 5 to 10 and 30 to $100 \mu \mathrm{m}$ size classes in which no clearance was performed.

The contribution of the 4 main taxomic guilds to total zooplankton clearance within seston size fractions is shown in Fig. 5. Particles of the smallest size fraction $(<2 \mu \mathrm{m})$ were exclusively cleared by appendicularians and bivalve veligers. As particle size increased, the portion cleared by copepods increased from $57 \%$ ( $<5 \mu \mathrm{m}$ size class) to more than $81 \%$ (30 to $100 \mu \mathrm{m}$ size class). When the relative clearance of adult copepods and nauplii was summed, the total copepod clearance accounted for 90 to $97.6 \%$ of the total volume cleared from particles bigger than $10 \mu \mathrm{m}$. The contribution of bivalve veligers dropped from $19 \%$ in the $<5 \mu \mathrm{m}$ size class to less than $3 \%$ in the 30 to $100 \mu \mathrm{m}$ seston size fraction. Appendicularians, in contrast, mainly cleared particles of the $<2 \mu \mathrm{m}$ size class, accounting for more than $62 \%$ of the total clearance in this size fraction.

Mean carbon ingestion rates of seston particles $<100 \mu \mathrm{m}$ calculated for mean abundances of all 4 guilds in $1 \mathrm{~m}^{3}$ ranged from 0.024 to $0.186 \mathrm{mg} \mathrm{C} \mathrm{h}^{-1}$. The highest ingestion rate was found for copepods ( $\left.0.186 \mathrm{mg} \mathrm{C} \mathrm{h}^{-1}\right)$; all other guilds ingested particles at rates lower than $0.050 \mathrm{mg} \mathrm{C} \mathrm{h}^{-1}$. Nauplii and copepod ingestion rates thereby accounted for 66.1 and $15.4 \%$ of total carbon ingestion; bivalve veligers and appendicularians contributed 10.0 and $8.5 \%$, respectively.

\section{DISCUSSION}

\section{Methodological aspects}

In 2 out of 4 cases the concentration of animals in the experimental jars significantly affected radioactive uptake by zooplankton (Fig. 6). In both cases, higher abundances of zooplankton in the experimental jars led to a reduced uptake of radioactive tracer per indiviual, which proved to be highly significant $(p<0.005)$ for copepods in experiments using seston size fractions, and significant $(p<0.05)$ for bivalve veligers in experiments using phytoplankton cultures. Tracer cell concentration, however, did not seem to affect radioactive uptake by copepods (Fig. 7) (no data are available for bivalve veligers). Copepods, which are known to behave as optimal foragers, change food selectivity with particle type abundance (DeMott 1989). The addition of tracer cells at high concentrations might have induced copepods to switch to these as an alternative food source as the encounter rate with tracer-sized particles was enhanced. In our experiments the addition of tracer cells apparently did not affect copepod feeding strategy. 

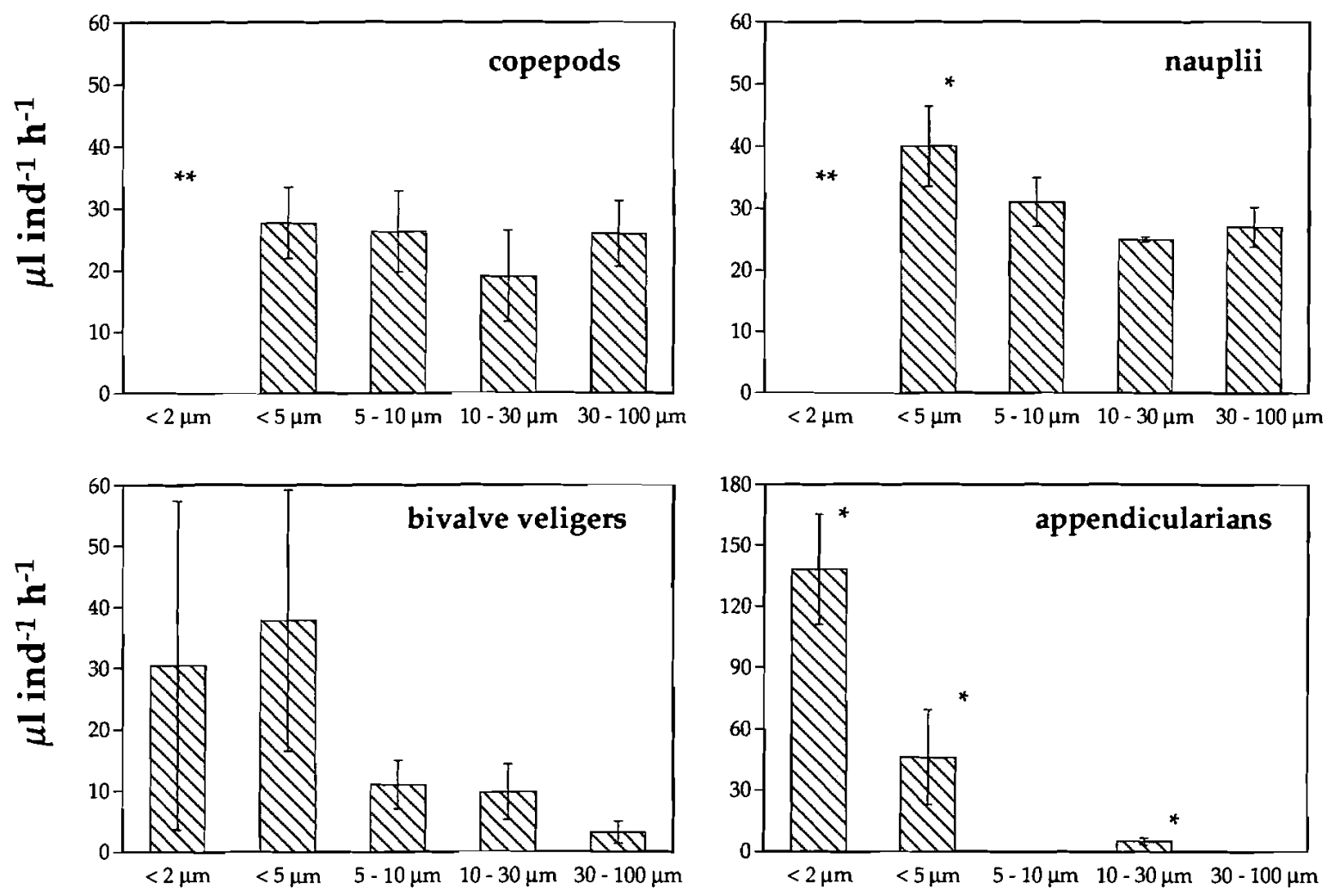

seston size fractions

\section{seston size fractions}

Fig. 4. Clearance rates ( $\mu$ lind..$^{-1} \mathrm{~h}^{-1}$ ) of the main mesozooplankton guilds, evaluated using radioactive labelled seston size fractions. Bars are means of triplicates; error bars represent $1 \mathrm{SD}^{*} \mathrm{p}<0.05, " \mathrm{p}<0.005$ (for details see text)

The clearance rates of appendicularians $(<165 \mu \mathrm{l}$ ind..$\left.^{-1} \mathrm{~h}^{-1}\right)$ and copepods $\left(<75 \mu \mathrm{l}\right.$ ind.$\left.^{-1} \mathrm{~h}^{-1}\right)$ in our experiments are lower than values reported in literature (e.g. Harris 1982, Berggreen et al. 1988, Bedo et al. 1993, Nakamura \& Turner 1997). Low clearance might have been a result of high particle concentrations in the seston or may be attributed, at least partly, to loss of radioactive label from the gut due to fixation in $4 \%$ formalin (Haney \& Hall 1973, Holtby \& Knoechel 1981). Other sources of error in using the isotope grazing technique are discussed in Roman \& Rublee (1980), White \& Roman (1992) or Roman \& Gauzens (1997).

\section{Size-specific clearance of bacteria and phytoplankton cultures}

Using a radioactive labelling technique, we determined the highest clearance of bivalve veligers and copepods for particles sized 4.7 and $6.3 \mu \mathrm{m}$ and for particles sized $15 \mu \mathrm{m}$, respectively. The highest veliger clearance of particles $<10 \mu \mathrm{m}$ is in accordance with previous results of some authors using phytoplankton cultures and natural seston (Table 4). A preference for

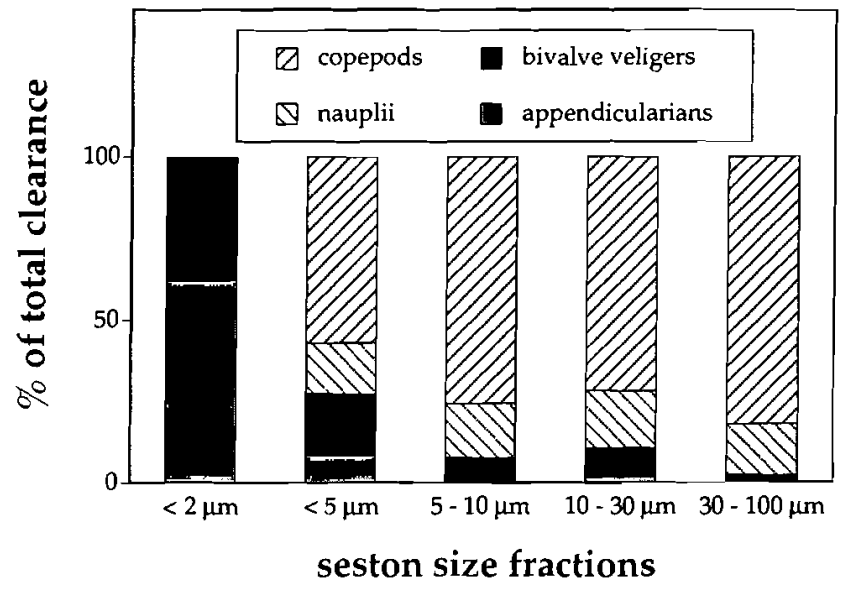

Fig. 5. Contribution of the main mesozooplankton guilds to total clearance within each seston size fraction. Clearance was calculated for mesozooplankton densities in $1 \mathrm{~m}^{3}$ seawater (see 'Material and methods')

particles sized 2.5 to $3.5 \mu \mathrm{m}$ (Riisgård et al. 1980) and 2 to $4 \mu \mathrm{m}$ (Baldwin 1995) has been reported for bivalve veligers, and of 4 to $6 \mu \mathrm{m}$ particles for a gastropod veliger (Hansen 1991). Furthermore, a study on the 

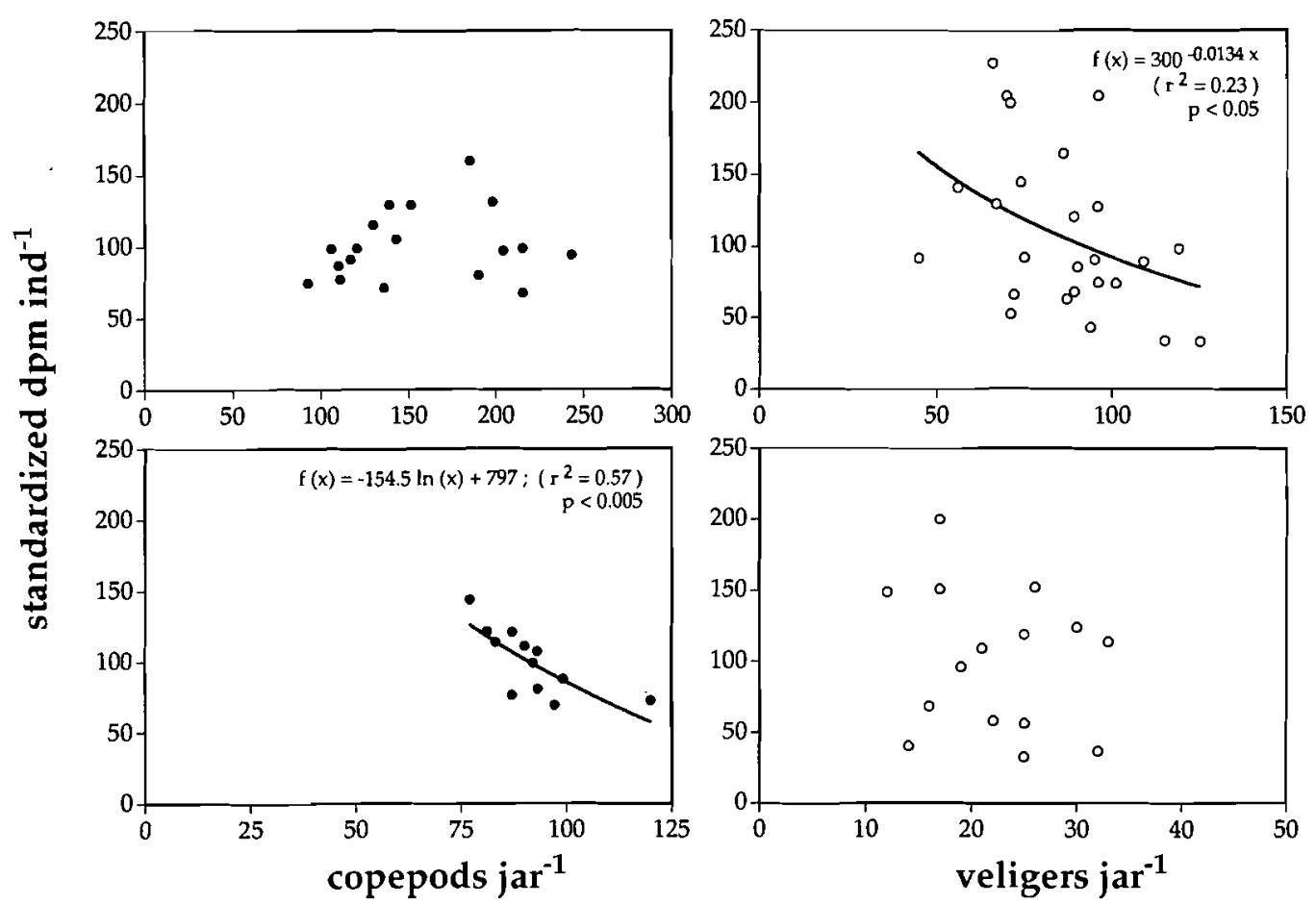

Fig. 6. Uptake of radioactive tracer by copepods (left panels) and bivalve veligers (right panels) as a function of grazer density in experimental jars. Each data point represents one value of experiments using labelled phytoplankton cultures (top panels) or seston size fractions (bottom panels). Dpm values were standardized by dividing replicate values by sample means and subsequent multiplication with 100 . Note different axis scaling. stomach contents of bivalve veliger larvae that had grazed upon the natural seston community revealed that all veligers contained cyanobacteria $<2 \mu \mathrm{m}$ and autotrophic flagellates $<5 \mu \mathrm{m}$, and only $55 \%$ of the larvae examined contained particles sized 5 to $15 \mu \mathrm{m}$. (Raby et al. 1997), supporting our results, which have shown main clearance of particles sized 4.7 and $6.3 \mu \mathrm{m}$.

Size-specific clearance by copepods can be related to 3 species that almost exclusively composed the copepod community: Pseudocalanus elongatus, Paracalanus parvus and Oithona similis, which together

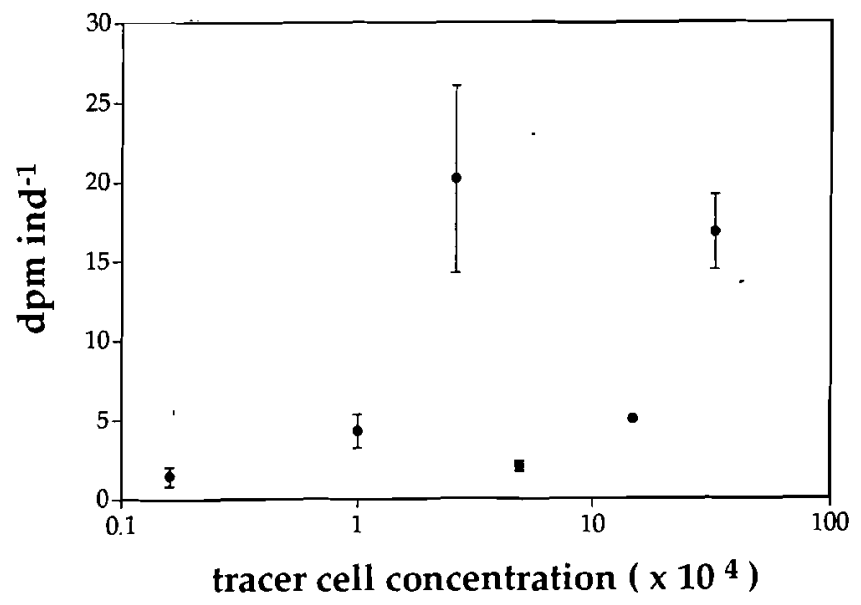

Fig. 7. Uptake of radioactive tracer by copepods as a function of tracer cell concentration in experiments using labelled phytoplankton cultures. Data points are means $(n=3)$; error bars represent $1 \mathrm{SD}$. Note logarithmic scale of particle size axis accounted for more than $90 \%$ of all copepods (Table 3 ). A study on the morphologies of the mouth parts of these 3 species classified $P$. elongatus and $P$. parvus as morphologically similar herbivores, capable of ingesting small particles, whereas $O$. similis has morphological traits typical of carnivores feeding on larger particles (Schnack 1982). Although a preference of bigger-sized cells ( $>10$ to $>20 \mu \mathrm{m}$ ) has been found for the herbivorous Paracalanus sp. (Pfaffenhöfer 1984) and Pseudocalanus minutus (Harris 1982), particles as small as $4.5 \mu \mathrm{m}$ can be cleared (Pfaffenhöfer 1984). Thereby Paracalanus sp. probably employs a passive feeding mode in capturing the small algae ( 4 to $6 \mu \mathrm{m}$ ), whereas bigger - in fact preferred - particles are actively grazed upon (Vanderploeg \& Pfaffenhöfer 1985). Ingestion of generally large particles (>10 to $250 \mu \mathrm{m}$ ) has also been found for other marine copepods, considered herbivores, including Calanus pacificus (Frost 1972), Acartia tonsa (Berggreen et al. 1988) and Eurytemora afinis (Merell \& Stoecker 1998). Removal experiments using the carnivore copepod Oithona similis showed no significant clearance of particles $<10 \mu \mathrm{m}$ and the highest clearance of particles $>20 \mu \mathrm{m}$ were mainly by ciliates and heterotrophic flagellates (Nakamura \& Turner 1997).

\section{Seston size fractions}

The results obtained in grazing experiments using seston size fractions showed that the smallest seston 
Table 4. Clearance rates and size preference of different veliger larvae

\begin{tabular}{|c|c|c|c|c|c|c|}
\hline Species & Size/age & Food & $\begin{array}{l}\text { Clearance rate } \\
\left(\mu l \text { ind. }{ }^{-1} h^{-1}\right)\end{array}$ & $\begin{array}{c}\text { Particle size } \\
\text { preference }(\mu \mathrm{m})\end{array}$ & Method & Source \\
\hline Mytilus edulis & No data & Isochrysis galbana & 11.4 & $2.5-3.5$ & Removal (Coulter) & Riisgård et al. (1980) \\
\hline Mercenaria mercenaria & $\begin{array}{l}2-10 \mathrm{~d} \\
2-10 \mathrm{~d}\end{array}$ & $\begin{array}{l}\text { Isochrysis galbana } \\
\text { Synechococcus }\end{array}$ & $\begin{array}{l}0.38-20.4 \\
17.4-67.2\end{array}$ & & Video image analysis & Gallager (1988) \\
\hline Crassostrea gigas & $\begin{array}{c}95-283 \mu \mathrm{m} \\
98 \mu \mathrm{m}\end{array}$ & $\begin{array}{l}\text { Bacterial strains } \\
\text { Isochrysis galbana }\end{array}$ & $\begin{array}{c}1.0-3.6 \\
1.9\end{array}$ & & Radioactive labelling & Douillet (1993) \\
\hline Mercenaria mercenaria & $6 \mathrm{~d}$ & Synechococcus & $2-23$ & & Epifluorescence microscopy & Gallager et al. (1994) \\
\hline Crassostrea virginica & $\begin{array}{l}179 \mu \mathrm{m} \\
179 \mu \mathrm{m} \\
237 \mu \mathrm{m} \\
273 \mu \mathrm{m}\end{array}$ & $\begin{array}{l}0.2-30 \mu \mathrm{m} \text { phototrophs } \\
0.2-30 \mu \mathrm{m} \text { heterotrophs } \\
\text { Isonema papillatum } \\
\text { Ciliate Smcil }\end{array}$ & $\begin{array}{c}82.5 \\
1.7 \\
64.0 \\
109.3\end{array}$ & $20-30$ & Radioactive labelling & Baldwin \& Newell (1991) \\
\hline $\begin{array}{l}\text { Phine operta } \\
\text { (gastropod larva!) }\end{array}$ & $149-392 \mu \mathrm{m}$ & $1.3-18 \mu \mathrm{m}$ algae & - & $4-6$ & Removal (Coulter) & Hansen (1991) \\
\hline Crassostrea virginica & $63-157 \mu \mathrm{m}$ & $<44 \mu \mathrm{m}$ seston & - & $>10$ & Removal & Fritz et al. (1984) \\
\hline Crassostrea virginica & $106-290 \mu \mathrm{m}$ & $0.2-30 \mu \mathrm{m}$ seston & - & $2-4^{\circ}$ & Removal (Coulter) & Baldwin (1995) \\
\hline Natural community ${ }^{\mathrm{a}}$ & $185-405 \mu \mathrm{m}$ & Seston & - & $<5$ & Epifluorescence microscopy & Raby et al. (1997) \\
\hline Natural community & $\begin{array}{l}>200 \mu \mathrm{m} \\
>200 \mu \mathrm{m}\end{array}$ & $\begin{array}{l}<0.8-21 \mu \mathrm{m} \text { tracer } \\
<100 \mu \mathrm{m} \text { tracer }\end{array}$ & $\begin{array}{c}0.97-21.9 \\
3.1-37.8\end{array}$ & $4.7-6.3$ & Radioactive labelling & This study \\
\hline
\end{tabular}

particles $(<2 \mu \mathrm{m})$ were exclusively ingested by appendicularians and, less pronounced, by bivalve veligers, whereas particles $>5 \mu \mathrm{m}$ were grazed upon by copepods, nauplii and veligers. As clearance within the $<5 \mu \mathrm{m}$ seston size fraction can still be attributable to the removal of particles visible in Utermöhl chambers (e.g. Skeletonema costatum), clearance within the $<2 \mu \mathrm{m}$ seston size fraction would imply the ingestion of particles detectable only under epifluorescent light (Table 2), thus suggesting that heterotrophic bacteria, cyanobacteria and flagellates $(\leq 2 \mu \mathrm{m})$ escape predation by copepods.

Baldwin \& Newell (1991) employed a similar method of radioactive labelled size fractionation and found that veligers of Crassostrea virginica cleared 0.2 to $30 \mu \mathrm{m}$ ${ }^{14} \mathrm{C}$ - and ${ }^{3} \mathrm{H}$-labelled seston particles at a (summed) rate of $84.2 \mu$ larva $^{-1} \mathrm{~h}^{-1}$ (Table 4 ). In our experiments veligers cleared particles $<2$ to $30 \mu \mathrm{m}$ at a similar (summed) rate of $119 \mu$ larva $^{-1} \mathrm{~h}^{-1}$. The particle size preference found by Baldwin \& Newell (1991) was for the 20 to $30 \mu \mathrm{m}$ fraction (Table 4), which is in contrast to later experiments by Baldwin (1995), which indicated a preference for smaller-sized particles (2 to $4 \mu \mathrm{m})$. The results of our experiments using seston size fractions, however, did not show any significant differences between veliger clearance rates over a broad size spectrum of food particles ( $<2$ to $100 \mu \mathrm{m}$ ) and failed to confirm the significant particle size preference $(4.7$ and $6.3 \mu \mathrm{m})$ found in phytoplankton culture experiments. As stated for the larvae of $C$. virginica, veliger larvae apparently extend their maximum ingested particle size in the presence of blooms (Baldwin \& Newell 1995a) and seem to select particles based more on their volume and nutritional quality than on particle size or abundance (Baldwin \& Newell 1995b), a fact that has been well documented for copepods (e.g. Houde \& Roman 1987, Cowles et al. 1988, DeMott 1988, 1989).

Copepods and nauplii, which represented more than 61 and $11 \%$ of the mesozooplankton in Kiel Bight (Table 3), accounted for 66.1 and $15.4 \%$ of the total ingested carbon of seston particles $<100 \mu \mathrm{m}$, respectively. Bivalve veligers and appendicularians contributed 10.0 and $8.5 \%$, respectively, to the total carbon ingestion rate. White \& Roman (1992) performed grazing measurements using radioactive labelling in a mesohaline bay that, similar to Kiel Bight, lacked planktonic groups such as echinoderm larvae and salps. They found, except for a bloom situation of polychaete larvae, similarly high values of contribution to total carbon ingestion for copepods ( 46.5 to $77.5 \%$ ), higher values for nauplii (18.9 to $52.3 \%$ ) and much lower ones for bivalve veligers ( 0 to $2.5 \%$ ). The contribution of copepods and nauplii to total carbon ingestion in this bay proved to be even higher (87.6 to $98.8 \%$ ) than in our experiments with zooplankton from Kiel Bight $(81.5 \%)$.

\section{CONCLUSIONS}

\section{Food size spectrum}

The results of our experiments with phytoplankton cultures are in accordance with earlier findings and suggest different optimum food particle sizes for bi- 
valve veligers and copepods (Fig. 3). Such a clear separation of optimum particle size, however, seems subject to flexible variation as the composition and nutritional quality of seston particles (e.g. blooms) varies (Fig. 4, Baldwin \& Newell 1995a).

\section{Ecological implications in Kiel Bight}

Due to high abundances throughout the year (Fig. 1) and the capabilities of clearing particles within a broad size range (Fig. 5), copepods proved to be the functionally dominant mesozooplankton guild in Kiel Bight. Nauplii and adult copepods together accounted for $81.5 \%$ of the total particulate carbon removed per hour. However, main grazers on particles in the range of the smallest members of the plankton were found to be bivalve veligers and, even more pronounced, appendicularians (Fig. 5).

Grazing by bivalve veligers can be seen as an important trophic link in the water column (other than the main carbon flow phytoplankton-copepod-fish) which utilizes carbon sources, such as heterotrophic bacteria and small flagellates $(\leq 2 \mu \mathrm{m})$, which escape predation by copepods. In terms of energetics, the ingestion of these small particles directs carbon towards the benthos when veliger larvae settle.

Acknowledgements. We are especially grateful to the members of the Department of Marine Botany, Institut für Meereskunde in Kiel. We also wish to thank T. Hansen for useful comments and technical assistance, $U$. Rabsch for his advice on radioactive labelling and $G$. Behrends for her help in identifying copepods. This work is a contribution to the EU-MAST III project COMWEB.

\section{LITERATURE CITED}

Alcarez M, Pfaffenhöfer GA, Strickler JR (1980) Catching the algae: a first account of visual observations on filter feeding calanoids. Am Soc Limnol Oceanogr Spec Symp 3: 241-248

Baldwin BS (1995) Selective particle ingestion by oyster larvae (Crassostrea virginica) feeding on natural seston and cultured algae. Mar Biol 123:95-107

Baldwin BS, Newell RIE (1991) Omnivorous feeding by planktonic larvae of the eastern oyster Crassostrea virginica. Mar Ecol Prog Ser 78:285-301

Baldwin BS, Newell RIE (1995a) Relative importance of different size food particles in the natural diet of oyster larvae (Crassostrea virginica). Mar Ecol Prog Ser 120:135-145

Baldwin BS, Newell RIE (1995b) Feeding rate responses of oyster larvae (Crassostrea virginica) to seston quantity and composition. J Exp Mar Biol Ecol 189:77-91

Bedo AW, Acuña JL, Robins D, Harris RP (1993) Grazing in the micron and sub-micron particle size range: the case of Oikopleura dioica (Appendicularia). Bull Mar Sci 53:2-14

Behrends G (1996) Long-term investigation of seasonal mesozooplankton dynamics in Kiel Bight, Germany. Proc 13th Symp Baltic Mar Biol, p 93-98
Berggreen U, Hansen B, Kiørboe T (1988) Food size spectra, ingestion and growth of the copepod Acartia tonsa during development: implications for determination of copepod production. Mar Biol 99:341-352

Bundy MH, Gross TF, Vanderploeg HA, Strickler JR (1998) Perception of inert particles by calanoid copepods: behavioral observations and a numerical model. J Plankton Res 20:2129-2152

Cowles TJ, Olson RJ, Chrisholm SW (1988) Food selection by copepods: discrimination on the basis of food quality. Mar Biol 100:41-49

Cushing DH (1975) Marine ecology and fisheries. Cambridge University Press, Cambridge

DeMott W (1988) Discrimination between algae and artificial particles by freshwater and marine copepods. Limnol Oceanogr 33:397-408

DeMott W (1989) Optimal foraging theory as a predictor of chemically mediated food selection by suspension-feeding copepods. Limnol Oceanogr 34:140-154

Douillet PA (1993) Carbon contribution through bactivory in larvae of the Pacific oyster Crassostrea gigas. Mar Ecol Prog Ser 102:303-314

Drebes G (1974) Marine Phytoplankton. Georg Thierne Verlag, Stuttgart

Fritz LW, Lutz RA, Foote MA, Van Dover CL, Ewart JW (1984) Selective feeding and grazing rates of oyster (Crassostrea virginica) larvae on natural phytoplankton assemblages. Estuaries 7:513-518

Frost BW (1972) Effects of size and concentration of food particles on the feeding behavior of the marine planktonic copepod Calanus pacificus. Limnol Oceanogr 17: 805-815

Gallager SM, Waterbury JB, Stoecker DK (1994) Efficient grazing and utilization of the marine cyanobacterium Synechococcus sp. by larvae of the bivalve Mercenaria mercenaria. Mar Biol 119:251-259

Haney JF (1971) An in situ method for the measurement of zooplankton grazing rates. Limnol Oceanogr 16:970-976

Haney JF, Hall DJ (1973) Sugar-coated Daphnia: a preservation technique for Cladocera. Limnol Oceanogr 18: $331-333$

Hansen B (1991) Feeding behaviour in larvae of the opisthobranch Philine aperta. II. Food size spectra and particle selectivity in relation to larval behaviour and morphology of the velar structure. Mar Biol 111:263-270

Harris RP (1982) Comparison of the feeding behaviour of Calanus and Pseudocalanus in two experimentally manipulated enclosed ecosystems. J Mar Biol Assoc UK 62: 71-91

Holtby LB, Knoechel R (1981) Zooplankton filtering rates: error due to loss of radioisotopic label in chemically preserved samples. Limnol Oceanogr 26:774-780

Houde SEL, Roman MR (1987) Effects of food quality on the functional ingestion response of the copepod Acartia tonsa. Mar Ecol Prog Ser 40:69-77

Kautsky H (1981) On the trophic role of the blue mussel (Mytilus edulis L.) in a Baltic coastal ecosystem and the fate of the organic matter produced by the mussels. Kiel Meeresforsch 5:454-461

Kleppel GS (1993) On the diets of calanoid copepods. Mar Ecol Prog Ser 99:183-195

Merell JR, Stoecker DK (1998) Differential grazing on protozoan microplankton by developmental stages of the calanoid copepod Eurytemora affinis Poppe. J Plankton Res 20:289-304

Nakamura Y, Turner JT (1997) Predation and respiration by the small cyclopoid copepod Oithona similis: how impor- 
tant is feeding on ciliates and heterotrophic flagellates? J Plankton Res 19:1275-1288

Pfaffenhöfer GA (1984) Food ingestion by the marine planktonic copepod Paracalanus in relation to abundance and size distribution of food. Mar Biol 80:323-333

Prieur D (1983) Ingestion et digestion de bacteries par les larves de la moule, Mytilus edulis. J Molluscan Stud (Suppl)12A:149-153

Raby D, Mingelbier M, Dodson JJ, Klein B, Lagadeuc Y, Legendre L (1997) Food-particle size and selection by bivalve larvae in a temperate embayment. Mar Biol 127: $665-672$

Riisgård HU, Randløv A, Kristensen PS (1980) Rates of water processing, oxygen consumption and efficiency of particle retention in veligers and young post-metamorphic Mytilus edulis. Ophelia 19:37-47

Roman MR, Gauzens AL (1997) Copepod grazing in the equatorial Pacific. Limnol Oceanogr 42:623-634

Editorial responsibility: Otto Kinne (Editor),

Oldendorf/Luhe, Germany
Roman MR, Rublee PA (1980) Containment effects in copepod grazing experiments: a plea to end the black box approach. Limnol Oceanogr 25:982-990

Schnack SB (1982) The structure of the mouth parts of copepods in Kiel Bay. Reports on Marine Science. Ber Dtsch Wiss Komm Meeresforsch. 29:89-101

Vanderploeg HA, Pfaffenhöfer GA (1985) Modes of algal capture by the freshwater copepod Diaptomus sicilis and their relation to food-size selection. Limnol Oceanogr 30: 871-885

Von Stosch HA, Drebes G (1964) Entwicklungsgeschichtliche Untersuchungen an zentrischen Diatomeen IV. Die Planktondiatomee Stephanopyxis turris - ihre Behandlung und Entwicklungsgeschichte. Helgol Wiss Meeresunters 11: 209-257

White JR, Roman MR (1992) Seasonal study of grazing by metazoan zooplankton in the mesohaline Chesapeake Bay. Mar Ecol Prog Ser 86:251-261

Submitted: August 18, 1999; Accepted: February 1, 2000 Proofs received from author(s): May 29, 2000 